\title{
Low-Temperature Virus vB_EcoM_VR26 Shows Potential in Biocontrol of STEC O26:H11
}

\author{
Aurelija Zajančkauskaitè, Algirdas Noreika, Rasa Rutkienė, Rolandas Meškys (D) and Laura Kaliniene *(D)
}

Citation: Zajančkauskaitè, A.; Noreika, A.; Rutkienè, R.; Meškys, R.; Kaliniene, L. Low-Temperature Virus vB_EcoM_VR26 Shows Potential in Biocontrol of STEC O26:H11. Foods 2021, 10, 1500. https://doi.org/ $10.3390 /$ foods 10071500

Academic Editors: Vicente M. Gómez-López and Julie Jean

Received: 4 June 2021

Accepted: 25 June 2021

Published: 28 June 2021

Publisher's Note: MDPI stays neutral with regard to jurisdictional claims in published maps and institutional affiliations.

Copyright: (c) 2021 by the authors. Licensee MDPI, Basel, Switzerland. This article is an open access article distributed under the terms and conditions of the Creative Commons Attribution (CC BY) license (https:// creativecommons.org/licenses/by/ $4.0 /)$.
Department of Molecular Microbiology and Biotechnology, Institute of Biochemistry, Life Sciences Center, Vilnius University, Sauletekio av. 7, LT-10257 Vilnius, Lithuania; aurelija.zajanckauskaite@bchi.vu.lt (A.Z.); algirdas.noreika@gmc.vu.lt (A.N.); rasa.rutkiene@bchi.vu.lt (R.R.); rolandas.meskys@bchi.vu.lt (R.M.)

* Correspondence: laura.kaliniene@bchi.vu.lt; Tel.: +370-5-2234384

\begin{abstract}
Shiga toxin-producing Escherichia coli (STEC) O26:H11 is an emerging foodborne pathogen of growing concern. Since current strategies to control microbial contamination in foodstuffs do not guarantee the elimination of $\mathrm{O} 26: \mathrm{H} 11$, novel approaches are needed. Bacteriophages present an alternative to traditional biocontrol methods used in the food industry. Here, a previously isolated bacteriophage vB_EcoM_VR26 (VR26), adapted to grow at common refrigeration temperatures ( 4 and $8{ }^{\circ} \mathrm{C}$ ), has been evaluated for its potential as a biocontrol agent against O26:H11. After $2 \mathrm{~h}$ of treatment in broth, VR26 reduced O26:H11 numbers $(p<0.01)$ by $>2 \log _{10}$ at $22{ }^{\circ} \mathrm{C}$, and $\sim 3 \log _{10}$ at $4{ }^{\circ} \mathrm{C}$. No bacterial regrowth was observed after $24 \mathrm{~h}$ of treatment at both temperatures. When VR26 was introduced to O26:H11-inoculated lettuce, $2.0 \log _{10} \mathrm{CFU} /$ piece reduction was observed at 4, 8, and $22{ }^{\circ} \mathrm{C}$. No survivors were detected after 4 and $6 \mathrm{~h}$ at 8 and $4{ }^{\circ} \mathrm{C}$, respectively. Although at $22{ }^{\circ} \mathrm{C}$, bacterial regrowth was observed after $6 \mathrm{~h}$ of treatment, $\mathrm{O} 26: \mathrm{H} 11$ counts on non-treated samples were $>2 \log _{10} \mathrm{CFU} /$ piece higher than on phage-treated ones $(p<0.02)$. This, and the ability of VR26 to survive over a $\mathrm{pH}$ range of 3-11, indicates that VR26 could be used to control STEC O26:H11 in the food industry.
\end{abstract}

Keywords: phage; biocontrol; VR26; STEC; O26:H11

\section{Introduction}

Escherichia coli (E. coli) is a gram-negative, facultatively anaerobic, rod-shaped bacterium of the genus Escherichia, family Enterobacteriaceae, that is commonly found in the gut of humans and warm-blooded animals [1]. Since the bacterium is routinely shed into the environment through feces, it can contaminate drinking water, irrigation water, and soil. Consequently, it can be transmitted to humans primarily through the consumption of contaminated foods [2,3]. Most strains of E. coli are non-pathogenic, however, a number of strains, such as Shiga toxin-producing E. coli (STEC), can cause severe foodborne disease. The Food and Agriculture Organization (FAO) together with the World Health Organization (WHO) estimated that more than 1.2 million new cases resulting in 128 deaths and nearly 13,000 Disability Adjusted Life Years (DALYs) occur each year because of contamination by the foodborne STEC [4]. Based on the results of outbreak surveillance data, the most frequently attributed sources of STEC globally were: beef $(16 \%)$, produce (fruits and vegetables, especially leafy greens; $15 \%)$, and dairy products $(6 \%)[3,4]$. The association of STEC with produce presents a serious problem because these products are minimally processed. Moreover, STEC strains have been shown to be adapted to survive for prolonged periods on plants and are often resistant to washing and chemical sanitizers [5-8]. As a result, contamination of fresh produce is emerging as a major food safety challenge, suggesting that current strategies to control microbial population during the production of fresh produce do not guarantee the elimination of STEC [2,8-12]. Hence, novel approaches are urgently needed for controlling these foodborne pathogens. 
A promising alternative in the food industry for the elimination of STEC from fresh produce is bacteriophages (phages): viruses that infect and kill bacteria [13]. There are many advantages of using phages in the biocontrol of foodborne pathogens. First, due to high specificity, bacteriophages target only specific bacteria without disturbing the normal microflora of foods. Second, while harmless to humans, phages are able to kill even multidrug-resistant bacteria. Third, phage preparations are considered the most environmentally-friendly antimicrobials since, usually, they contain only natural (genetically unmodified) phages in a weak saline solution [13]. In 2006 the US Food and Drug Administration (FDA) approved the use of a first bacteriophage preparation (LMP-102) to be used against Listeria monocytogenes on foods [14]. Since then, a number of phage products (such as ListShield ${ }^{\mathrm{TM}}$, EcoShield ${ }^{\mathrm{TM}}$, and SalmoFresh ${ }^{\mathrm{TM}}$ by Intralytix, and Listex ${ }^{\mathrm{TM}}$ P100 by Micreos) have been commercialized and have been approved for use in a growing number of countries $[13,15]$. Moreover, over the past 10 years, the number of research reports describing the use of phage biocontrol to target a variety of bacterial pathogens in various foods have increased dramatically $[13,15]$. With regard to STEC serotypes, however, most phage preparations, and therefore studies, have predominantly focused on O157:H7 [13,15-17].

The most common STEC serotype associated with human disease is, indeed, O157:H7 [2,4,18]. However, a growing number of foodborne human STEC infections are caused by non-O157 strains, among which O26:H11 is most frequently associated with severe diarrhea and hemolytic uremic syndrome worldwide [4,19-22]. Nevertheless, to the best of our knowledge, only a few O26:H11-targeting phages are described in the literature [23-26] and even fewer of those have been evaluated for their ability to reduce numbers of O26:H11 in a broth culture system, under standard laboratory conditions $[27,28]$. None of these phages, however, have been tested for their ability to control this particular pathogen on fresh produce.

Previously, we presented the complete genome sequence of a T4-related E. coli phage vB_EcoM_VR26 (VR26) and showed that none of the predicted VR26 proteins exhibited sequence homology with known integration-related proteins, antibiotic resistance determinants, or virulence factors. [29]. VR26 is a low-temperature virus, adapted to replicate at temperatures suboptimal for its host $\left(<10^{\circ} \mathrm{C}\right)$. The vast majority of characterized coliphages are mesophilic viruses, plating in the range of 15 to $42{ }^{\circ} \mathrm{C}[29,30]$. To date, only seven E. coli phages, all belonging to the family Myoviridae, have been shown to be adapted to lyse their hosts at low temperatures $\left(4-7^{\circ} \mathrm{C}\right)[29,30]$. Due to their unique physiological properties, such phages have tremendous potential in food safety applications, where lytic activity at low temperatures is especially needed. Therefore, the objective of this study was to evaluate the efficacy of VR26 in biocontrol of STEC O26:H11 both in vitro and on fresh produce.

\section{Materials and Methods}

\subsection{Bacterial Strains and Culture Conditions}

Bacterial strains used in this study are listed in Table 1. STEC strains, isolated from food samples, were kindly provided by Prof. Edita Sužiedèlienè (Institute of Biosciences, Life Sciences Center, Vilnius University, Vilnius, Lithuania), whereas E. coli MH1 was a gift from Prof. Kenneth N. Kreuzer [31]. For inoculum preparation, bacteria were streaked on LB (Luria-Bertani) agar and the plates were incubated at $37^{\circ} \mathrm{C}$ for $24 \mathrm{~h}$. A single colony was then inoculated into $5 \mathrm{~mL}$ of LB broth and cultured overnight at $37^{\circ} \mathrm{C}$. Following incubation, $50 \mu \mathrm{L}$ of overnight culture was used to inoculate $5 \mathrm{~mL}$ of LB and incubated at $37^{\circ} \mathrm{C}$ with agitation until the optical density at $600 \mathrm{~nm}$ (OD600) reached 0.5. The cultures were then held on ice until ready for use. 
Table 1. Susceptibility of STEC isolates to VR26.

\begin{tabular}{cccccc}
\hline Strain/Serotype & $\mathbf{8}^{\circ} \mathbf{C}$ & Spot Test & $\mathbf{8}^{\circ} \mathbf{C}$ & EOP & $\mathbf{2 2}{ }^{\circ} \mathbf{C}$ \\
\hline O26:H11 & + & + & 0.89 & 1.0 \\
O157:H7 & - & - & - & - \\
O103:H2 & - & - & - & - \\
O111:H8 & - & - & - & - \\
O145:H128 & - & - & - & - \\
MH1 1 & + & + & 0.84 & 0.99 \\
\hline
\end{tabular}

${ }^{1}$ host strain; "+" —clear plaques were observed; "-"—no plaques; 1 - the largest number of plaques (taken as a standard in EOP calculation).

\subsection{Lytic Spectrum Determination}

First, the ability of phage VR26 to infect different serotypes of STEC at 22 and $8{ }^{\circ} \mathrm{C}$ was determined using a quantitative spot dilution test as described in [32]. The host was classified as sensitive when single plaques could be detected. Then, determination of the efficiency of plating (EOP) was performed as described in [29]. In both experiments, the plates were incubated at room temperature $\left(22^{\circ} \mathrm{C}\right)$ for $24 \mathrm{~h}$ and at $8{ }^{\circ} \mathrm{C}$ for $5-6$ days.

\section{3. $p H$ Tolerance of VR26}

To determine the effect of $\mathrm{pH}$ on the stability of phage VR26, $10 \mu \mathrm{L}$ of phage suspension $\left(\sim 11 \log _{10}\right.$ PFU/mL) was added to the tubes containing sterile PBS $(90 \mu \mathrm{L})$ with $\mathrm{pH}$ values ranging from 2 to 13 , adjusted with $\mathrm{NaOH}$ or $\mathrm{HCl}$. The tubes were allowed to incubate at $22{ }^{\circ} \mathrm{C}$ for $60 \mathrm{~min}$, then a double agar overlay plaque assay was performed [33]. Briefly, the phage solutions were serially diluted and plated in duplicate using STEC O26:H11 as a host. The plaques were counted, and the results were expressed as phage concentration $\left(\log _{10} \mathrm{PFU} / \mathrm{mL}\right)$.

\subsection{Bacterial Challenge Assay}

For the bacterial challenge assay, $5 \mathrm{~mL}$ of fresh bacterial culture, diluted to a final concentration of $4 \log _{10} \mathrm{CFU} / \mathrm{mL}$ with LB broth, was inoculated with VR26 at $2 \log _{10} \mathrm{PFU} / \mathrm{mL}$ and incubated at 4 and $22{ }^{\circ} \mathrm{C}$, at an agitation rate of $170 \mathrm{rpm}$. Culture without the addition of VR26 was used as a control. After 2, 4, 6, and $24 \mathrm{~h}$ of incubation, $100 \mu \mathrm{L}$ of each sample was withdrawn, serially diluted in PBS buffer, if necessary, and plated on LB agar. The plates were incubated at $37^{\circ} \mathrm{C}$. Bacterial viable counts were determined after overnight incubation.

\subsection{Treatment of Inoculated Fresh-Cut Lettuce with VR26}

Iceberg lettuce (Lactuca sativa) was purchased at a grocery store IKI in Vilnius (Lithuania). Outer leaves of the lettuce were removed whereas the inner leaves were cut into pieces of $\sim 1$ by $\sim 1 \mathrm{~cm}$ with a sterile, stainless steel scalpel. The samples were then transferred to the sterile Petri dishes and spot inoculated with $10 \mu \mathrm{L}$ of STEC O26:H11 $\left(4 \log _{10} \mathrm{CFU} / \mathrm{cm}^{2}\right)$. Inoculated lettuce was then treated with the phage VR26 suspension $\left(8 \log _{10} \mathrm{PFU} / \mathrm{cm}^{2}\right)$ or PBS (control) and the samples were stored at 4,8 and $22{ }^{\circ} \mathrm{C}$. After $2,4,6$, and 24 h of incubation, one sample per treatment was withdrawn, transferred to $2 \mathrm{ml}$ Eppendorf tube with $1 \mathrm{~mL}$ PBS, and then homogenized with sterile bars and vortexed. Homogenates or serial dilutions of homogenates were plated on LB agar, and bacterial viable counts were determined after overnight incubation at $37^{\circ} \mathrm{C}$.

\subsection{Statistical Analysis}

All experiments were run in triplicate and bacteria/phage counts were determined by duplicate plating. Colony counts are presented as mean values with standard deviation. Unpaired $t$-test (two-tailed) was employed to calculate the statistical significance $(p<0.05)$ between treatments and control. 


\section{Results and Discussion}

\subsection{Lytic Spectrum and $p H$ Tolerance of VR26}

Bacteriophage VR26 was tested against a set of 5 pathogenic E. coli, representing different STEC serotypes: O157:H7, O103:H2, O111:H8, O145:H128, and O26:H11. A quantitative spot dilution test (Table 1) revealed that VR26 was capable of infecting only O26:H11 isolate, with roughly the same efficiency at both temperatures tested $\left(8\right.$ and $\left.22{ }^{\circ} \mathrm{C}\right)$.

Phages that display a narrow lytic activity against non-O157 E. coli were also described in a study by Litt et al. [24], in which three viruses targeting O26:H11 failed to infect isolates representing other STEC serogroups, including O45, O103, O111, O121, and O145. While it has been suggested previously that broad-spectrum phages are preferred candidates for a number of phage-based applications $[23,24]$ phages with narrow host specificity could be used either to target a specific pathogen or in the development of phage cocktails with broad lytic activity against foodborne bacteria.

As seen in Table 1, VR26 had a slightly higher EOP on O26:H11 than it did on MH1. However, MH1 is a laboratory host which has been used for the isolation of bacteriophages, VR26 included, from the municipal wastewater samples [29]. Considering the origin of VR26, one could speculate that the natural host of this phage may just as well be a STEC strain.

Since STEC strains are known to tolerate a somewhat broad range of $\mathrm{pH}(4.0-9.0)$ [34], bacteriophages intended for use in phage-based biocontrol must retain their lytic activity under similar conditions. To examine the effect of $\mathrm{pH}$ on VR26, the $\mathrm{pH}$-inactivation assay ( $\mathrm{pH} 2.0$ to 12.0) was performed. As seen in Figure 1, VR26 was stable at $\mathrm{pH}$ values of 3-11, whereas significant reduction $\left(8-9 \log _{10} \mathrm{PFU} / \mathrm{mL}\right.$ ) in the viable titer was observed only after the exposure to extremely acidic $(\mathrm{pH} \leq 2)$ or basic $(\mathrm{pH} \geq 12)$ conditions.

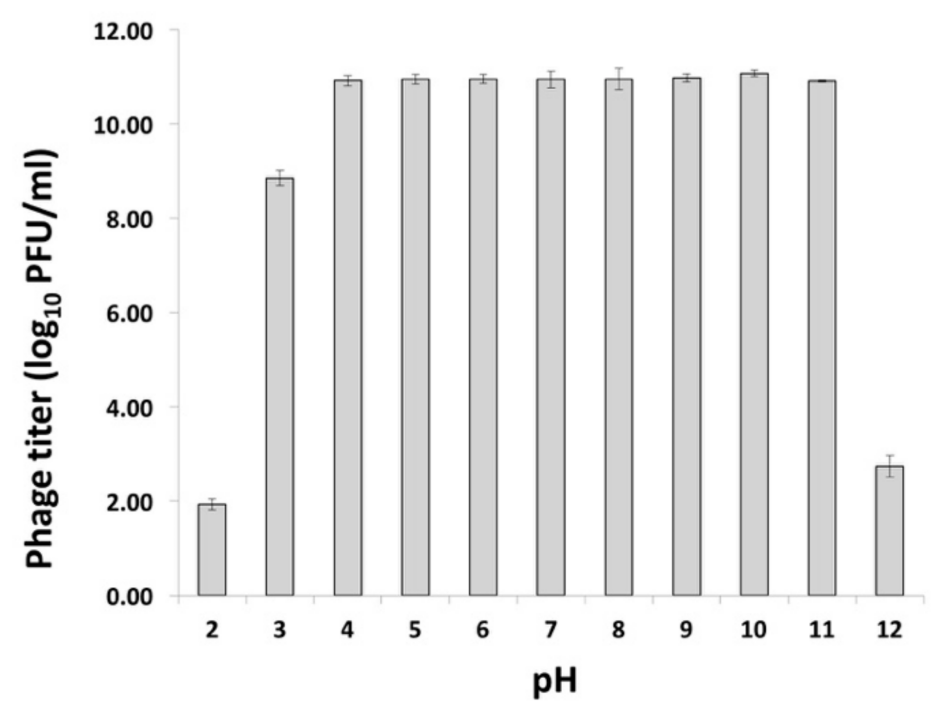

Figure 1. The effect of $\mathrm{pH}$ on VR26. Bars present standard deviation.

Taken together, the results of the $\mathrm{pH}$-inactivation assay suggested that VR26 sustained its lytic property through a broad range of $\mathrm{pHs}$, indicating greater stability of this phage compared with other O26:H11-infecting [24] or even O157:H7-infecting viruses [24,35-37] described in previous studies.

The ability of phages to survive acidic $(\mathrm{pH} \leq 5)$ or alkaline $(\mathrm{pH} \geq 7)$ conditions is a desirable trait in phage-based applications. It has been suggested previously that acidtolerant phages could be utilized to control pathogen colonization in the gastrointestinal tract ( $\mathrm{pH} 1-5)$ of food animals if used as animal feed and/or water supplements [24,38-40]. Such phages could also be used as biocontrol agents in acidic foods such as fruit juices, jams, and fermented products [24]. Moreover, bacteriophages capable of surviving both acidic and alkaline $\mathrm{pH}$ could be used to address contamination by foodborne pathogens 
at a variety of time points during food production; applying to livestock animals before processing, decontaminating food preparation surfaces, or treatment of post-harvest food products $[13,24]$.

\subsection{Bacterial Challenge Assay}

Compared with the phage-free controls, a significant reduction $(p<0.01)$ of O26:H11 in LB broth was observed after the addition of VR26, at both $22^{\circ} \mathrm{C}$ and $4{ }^{\circ} \mathrm{C}$ (Figure 2).

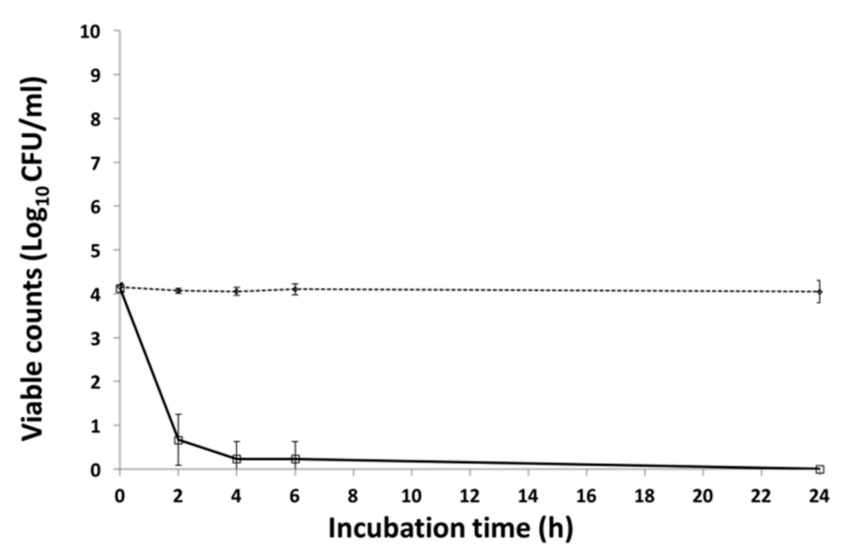

(a)

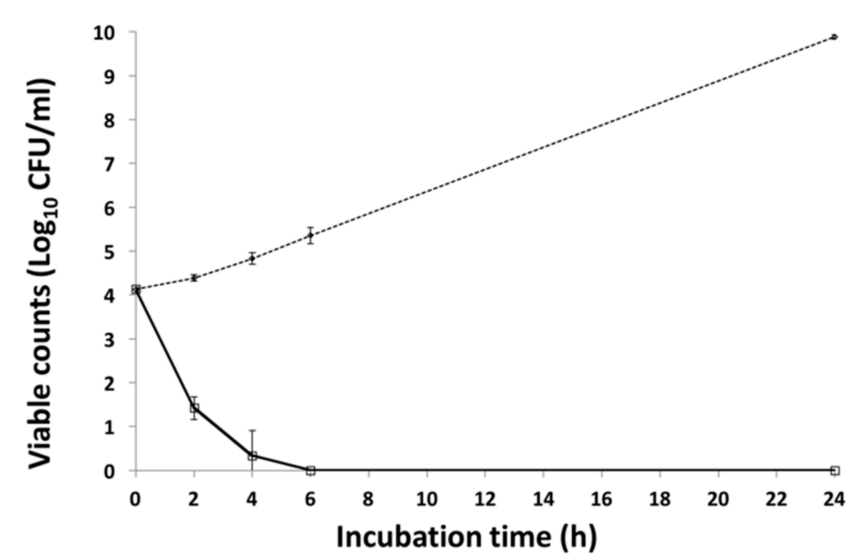

(b)

Figure 2. Effect of phage VR26 on numbers of STEC O26:H11 in LB medium at 4 (a) and $22{ }^{\circ} \mathrm{C}(\mathbf{b})$. Solid line, VR26-treated cultures; dashed line, control. Bars present standard deviation.

After $2 \mathrm{~h}$ of incubation VR26 reduced O26:H11 counts by more than $2 \log (p<0.01)$ at $22{ }^{\circ} \mathrm{C}$, and by approximately $3 \log (p<0.01)$ at $4{ }^{\circ} \mathrm{C}$. VR26 was able to reduce $(p<0.01)$ numbers of $\mathrm{O} 26: \mathrm{H} 11$ to $<10 \mathrm{CFU} / \mathrm{mL}$ after $4 \mathrm{~h}$ of incubation at $4{ }^{\circ} \mathrm{C}$, whereas, after $24 \mathrm{~h}$, the viable cells were not detected (Figure 2a). At $22{ }^{\circ} \mathrm{C}, \mathrm{O} 26: \mathrm{H} 11$ was undetectable $(<10 \mathrm{CFU} / \mathrm{mL})$ after $4 \mathrm{~h}$ of phage treatment and no bacterial regrowth was observed thereafter (Figure $2 b$ ).

As discussed above, two reports describing phages capable of reducing O26:H11 levels in a broth culture system under standard laboratory conditions may be found in literature [27,28]. In a study by Niu et al. [27], a polyvalent T5virus vB_EcoS_AKFV33 was shown to decrease the viable counts of O26:H11 in broth culture by $7.5 \pm 0.4 \log _{10} \mathrm{CFU} / \mathrm{mL}$ $(p<0.001)$ at $37^{\circ} \mathrm{C}$ but the efficacy of the phage $(p<0.001)$ was reduced after $7 \mathrm{~h}$ of incubation and regrowth of bacteria was seen thereafter. Mangieri et al. [28] reported that in $6 \mathrm{~h}$ at $37^{\circ} \mathrm{C}$ a cocktail containing coliphages FM10, DP16, and DP19 caused a substantial reduction in at least 1 out of 10 STEC O26 serogroup strains tested. However, in the latter study, viable cell enumeration was not performed and the measurement of optical density (OD) at $600 \mathrm{~nm}$ was used instead. Also, since the $\mathrm{H}$-antigen has not been specified by the authors, it is unclear how many of the aforementioned strains are of O26:H11 serotype.

The results presented here are hardly comparable with those obtained during the aforementioned studies since bacterial challenge with phage VR26 assay was performed at 4 and $22{ }^{\circ} \mathrm{C}$, not at $37^{\circ} \mathrm{C}$. However, in the food industry, foods are hardly ever exposed to $37^{\circ} \mathrm{C}$. Hence, the ability of VR26 to effectively reduce O26:H11 at both refrigeration and room temperature conditions indicates that this bacterial virus shows potential in the decontamination of foods, especially at post-harvest.

\subsection{Effect of VR26 on O26:H11 on Fresh Lettuce}

The ability of the phage VR26 to reduce O26:H11 on lettuce was examined at 4, 8, and $22{ }^{\circ} \mathrm{C}$. As seen in Figure 3, VR26 reduced $(p<0.02)$ the viable counts of O26:H11 by $\sim 2 \log _{10} \mathrm{CFU} /$ piece after $2 \mathrm{~h}$ of treatment at all temperatures. No survivors were detected after 6 and $4 \mathrm{~h}$ of treatment at 4 and $8{ }^{\circ} \mathrm{C}$, respectively. 


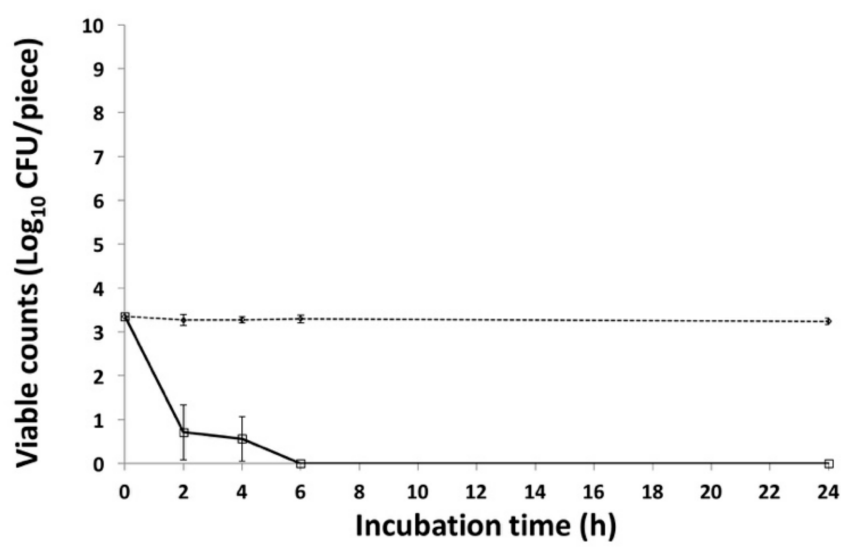

(a)

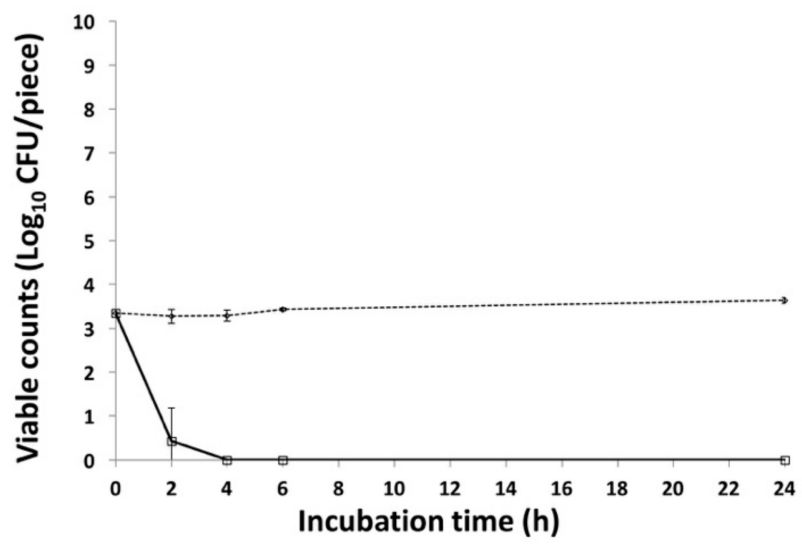

(b)

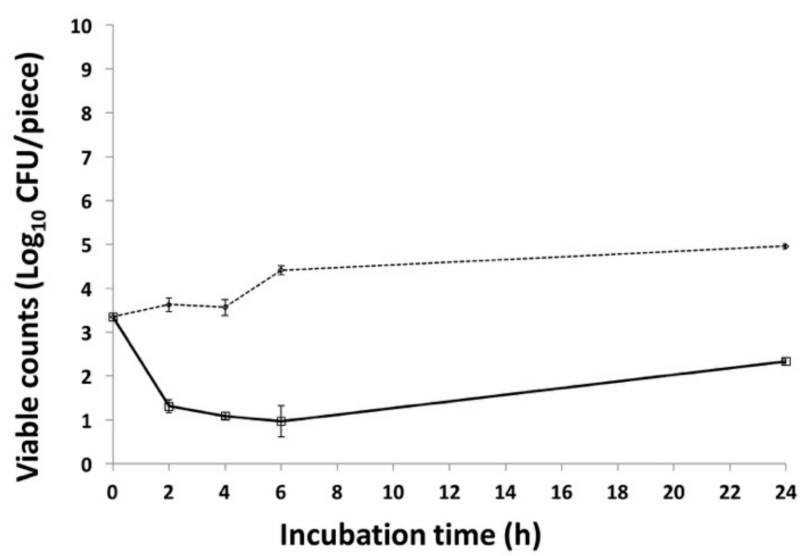

(c)

Figure 3. Effect of phage VR26 on numbers of STEC O26:H11 on fresh lettuce at 4 (a), 8 (b), and $22{ }^{\circ} \mathrm{C}(\mathrm{c})$. Solid line, VR26-treated lettuce pieces; dashed line, control. Bars present standard deviation.

At $22{ }^{\circ} \mathrm{C}$, the pathogen was reduced by more than $2 \log _{10} \mathrm{CFU}$ within $6 \mathrm{~h}$ and, although bacterial regrowth was observed afterward, O26:H11 counts on non-treated lettuce pieces were $>2 \log _{10} \mathrm{CFU} /$ piece higher than on phage-treated samples $\left(2.3 \pm 0.06 \log _{10} \mathrm{CFU} /\right.$ piece $)$ $(p<0.02)$.

Bacterial regrowth observed during phage treatment at room temperature was also reported by a number of previous studies [17,41-44] and could be explained either by the inability of viral particles to "move" and, consequently, to find all host-cells on solid foods or by the appearance of phage-resistant bacteria $[17,45,46]$. However, the probability of phage 
and cell coming into contact could be increased by applying higher phage concentrations, whereas, to prevent the emergence of phage resistance, so-called "phage cocktails" or phages in combination with other antibacterial agents could be used [17,47-50]. Moreover, in the modern food industry, the probability of foods being contaminated with high numbers of pathogenic microorganisms is relatively low [48] which, in itself, minimizes the occurrence of phage resistance.

\section{Conclusions}

Here, for the first time, the efficacy of low-temperature E. coli virus VR26 in the biocontrol of foodborne pathogens was evaluated. Our results clearly demonstrate that bacteriophage VR26 retained its lytic activity after being exposed to a range of $\mathrm{pH}$ from 3 to 11 and efficiently reduced O26:H11 counts, both in broth culture and on fresh lettuce, at all temperatures tested. Moreover, the greatest efficacy of VR26 on food was observed at common refrigeration temperatures $\left(4\right.$ and $\left.8{ }^{\circ} \mathrm{C}\right)$, suggesting that this phage could potentially be used as a biocontrol agent against STEC O26:H11 in the food industry.

Author Contributions: Conceptualization, L.K.; methodology, L.K.; investigation, L.K., A.Z., A.N., R.R., R.M.; writing—original draft preparation, L.K.; writing—review and editing, L.K., R.M., A.Z.; visualization, L.K., A.N.; project administration, L.K.; funding acquisition, L.K. All authors have read and agreed to the published version of the manuscript.

Funding: This research was funded by the Research Council of Lithuania, grant number S-MIP-19-58.

Institutional Review Board Statement: Not applicable.

Informed Consent Statement: Not applicable.

Data Availability Statement: The complete genome sequence of E. coli phage VR26 is available at the NCBI, accession number NC_028957.

Conflicts of Interest: The authors declare no conflict of interest. The funders had no role in the design of the study; in the collection, analyses, or interpretation of data; in the writing of the manuscript, or in the decision to publish the results.

\section{References}

1. Scheutz, F.; Strockbine, N.A. Escherichia. In Bergey's Manual of Systematics of Archaea and Bacteria; Trujillo, M.E., Dedysh, S., DeVos, P., Hedlund, B., Kämpfer, P., Rainey, F.A., Whitman, W.B., Eds.; John Wiley \& Sons: Hoboken, NJ, USA, 2015. [CrossRef]

2. Bhunia, A.K. Foodborne Microbial Pathogens: Mechanisms and Pathogenesis, 2nd ed.; Heldman, D.R., Ed.; Springer: New York, NY, USA, 2018. [CrossRef]

3. World Health Organization; Food and Agriculture Organization of the United Nations. Shiga Toxin-Producing Escherichia coli (STEC) and Food: Attribution, Characterization, and Monitoring: Report 2018. Available online: https://apps.who.int/iris/ handle/10665/272871 (accessed on 30 May 2021).

4. World Health Organization; Food and Agriculture Organization of the United Nations. Attributing Illness Caused by Shiga Toxin-Producing Escherichia coli (STEC) to Specific Foods: Report 2019. Available online: https://apps.who.int/iris/handle/10 $665 / 326923$ (accessed on 30 May 2021).

5. Hoagland, L.; Ximenes, E.; Ku, S.; Ladisch, M. Foodborne pathogens in horticultural production systems: Ecology and mitigation. Sci. Hortic. 2018, 236, 192-206. [CrossRef]

6. Yu, K.; Newman, M.C.; Archbold, D.D.; Hamilton-Kemp, T.R. Survival of Escherichia coli O157:H7 on Strawberry Fruit and Reduction of the Pathogen Population by Chemical Agents. J. Food Prot. 2001, 64, 1334-1340. [CrossRef] [PubMed]

7. Jagannathan, B.V.; Kitchens, S.; Vijayakumar, P.P.; Price, S.; Morgan, M. Potential for Bacteriophage Cocktail to Complement Commercial Sanitizer Use on Produce against Escherichia coli O157:H7. Microorganisms 2020, 8, 1316. [CrossRef] [PubMed]

8. Balali, G.I.; Yar, D.; Dela, V.G.A.; Adjei-Kusi, P. Microbial Contamination, an Increasing Threat to the Consumption of Fresh Fruits and Vegetables in Today's World. Int. J. Microbiol. 2020, 2020, 3029295. [CrossRef] [PubMed]

9. Hess, T.; Sutcliffe, C. The exposure of a fresh fruit and vegetable supply chain to global water-related risks. Water Int. 2018, 43, 746-761. [CrossRef]

10. Hussain, M.A.; Gooneratne, S.R. Understanding the Fresh Produce Safety Challenges. Foods 2017, 6, 23. [CrossRef]

11. Luna-Guevara, J.J.; Arenas-Hernandez, M.M.P.; de la Peña, C.M.; Silva, J.L.; Luna-Guevara, M.L. The Role of PathogenicE. coliin Fresh Vegetables: Behavior, Contamination Factors, and Preventive Measures. Int. J. Microbiol. 2019, 2019, 1-10. [CrossRef]

12. European Food Safety Authority. Urgent advice on the public health risk of Shiga-toxin producing Escherichia coli in fresh vegetables. EFSA J. 2011, 9, 2274. [CrossRef] 
13. Moye, Z.D.; Woolston, J.; Sulakvelidze, A. Bacteriophage Applications for Food Production and Processing. Viruses 2018, 10, 205. [CrossRef]

14. Lang, L.H. FDA Approves Use of Bacteriophages to be Added to Meat and Poultry Products. Gastroenterology 2006, 131, 1370. [CrossRef]

15. Pinto, G.; Almeida, C.; Azeredo, J. Bacteriophages to control Shiga toxin-producing E. coli-Safety and regulatory challenges. Crit. Rev. Biotechnol. 2020, 40, 1081-1097. [CrossRef]

16. Ferguson, S.; Roberts, C.; Handy, E.; Sharma, M. Lytic bacteriophages reduce Escherichia coliO157: H7 on fresh cut lettuce introduced through cross-contamination. Bacteriophage 2013, 3, e24323. [CrossRef] [PubMed]

17. Duc, H.M.; Son, H.M.; Yi, H.P.S.; Sato, J.; Ngan, P.H.; Masuda, Y.; Honjoh, K.-I.; Miyamoto, T. Isolation, characterization and application of a polyvalent phage capable of controlling Salmonella and Escherichia coli O157:H7 in different food matrices. Food Res. Int. 2020, 131, 108977. [CrossRef]

18. Marshall, K.E.; Hexemer, A.; Seelman, S.L.; Fatica, M.K.; Blessington, T.; Hajmeer, M.; Kisselburgh, H.; Atkinson, R.; Hill, K.; Sharma, D.; et al. Lessons Learned from a Decade of Investigations of Shiga Toxin-Producing Escherichia coli Outbreaks Linked to Leafy Greens, United States and Canada. Emerg. Infect. Dis. 2020, 26, 2319-2328. [CrossRef] [PubMed]

19. Delannoy, S.; Mariani-Kurkdjian, P.; Bonacorsi, S.; Liguori, S.; Fach, P. Characteristics of Emerging Human-Pathogenic Escherichia coli O26:H11 Strains Isolated in France between 2010 and 2013 and Carrying thestx2dGene Only. J. Clin. Microbiol. 2014, 53, 486-492. [CrossRef] [PubMed]

20. Dallman, T.J.; Greig, D.R.; Gharbia, S.E.; Jenkins, C. Phylogenetic context of Shiga toxin-producing Escherichia coli serotype O26:H11 in England. Microb. Genom. 2019, 7, 000551. [CrossRef]

21. Ogura, Y.; Gotoh, Y.; Itoh, T.; Sato, M.P.; Seto, K.; Yoshino, S.; Isobe, J.; Etoh, Y.; Kurogi, M.; Kimata, K.; et al. Population structure of Escherichia coli O26:H11 with recent and repeated stx2 acquisition in multiple lineages. Microb. Genom. 2017, $3,000141$. [CrossRef] [PubMed]

22. European Food Safety Authority and European Centre for Disease Prevention and Control. The European Union summary report on trends and sources of zoonoses, zoonotic agents and food-borne outbreaks in 2015. EFSA J. 2016, 14, 4634.

23. Bumunang, E.W.; McAllister, T.A.; Stanford, K.; Anany, H.; Niu, Y.D.; Ateba, C.N. Characterization of Non-O157 STEC Infecting Bacteriophages Isolated from Cattle Faeces in North-West South Africa. Microorganisms 2019, 7, 615. [CrossRef]

24. Litt, P.K.; Saha, J.; Jaroni, D. Characterization of Bacteriophages Targeting Non-O157 Shiga Toxigenic Escherichia coli. J. Food Prot. 2018, 81, 785-794. [CrossRef]

25. Wang, J.; Niu, Y.D.; Chen, J.; Anany, H.; Ackermann, H.-W.; Johnson, R.P.; Ateba, C.N.; Stanford, K.; McAllister, T.A. Feces of feedlot cattle contain a diversity of bacteriophages that lyse non-O157 Shiga toxin-producing Escherichia coli. Can. J. Microbiol. 2015, 61, 467-475. [CrossRef] [PubMed]

26. Liao, Y.-T.; Sun, X.; Quintela, I.A.; Bridges, D.F.; Liu, F.; Zhang, Y.; Salvador, A.; Wu, V.C.H. Discovery of Shiga Toxin-Producing Escherichia coli (STEC)-Specific Bacteriophages from Non-fecal Composts Using Genomic Characterization. Front. Microbiol. 2019, 10, 627. [CrossRef] [PubMed]

27. Niu, Y.D.; Liu, H.; Johnson, R.P.; McAllister, T.A.; Stanford, K. Effect of a bacteriophage T5virus on growth of Shiga toxigenic Escherichia coli and Salmonella strains in individual and mixed cultures. Virol. J. 2020, 17, 1-7. [CrossRef] [PubMed]

28. Mangieri, N.; Picozzi, C.; Cocuzzi, R.; Foschino, R. Evaluation of a Potential Bacteriophage Cocktail for the Control of Shiga-Toxin Producing Escherichia coli in Food. Front. Microbiol. 2020, 11, 1801. [CrossRef] [PubMed]

29. Kaliniene, L.; Zajančkauskaite, A.; Šimoliūnas, E.; Truncaitè, L.; Meškys, R. Low-temperature bacterial viruses VR-A small but diverse group of E. coli phages. Arch. Virol. 2015, 160, 1367-1370. [CrossRef]

30. Jurczak-Kurek, A.; Gąsior, T.; Nejman-Faleńczyk, B.; Bloch, S.; Dydecka, A.; Topka, G.; Necel, A.; Jakubowska-Deredas, M.; Narajczyk, M.; Richert, M.; et al. Biodiversity of bacteriophages: Morphological and biological properties of a large group of phages isolated from urban sewage. Sci. Rep. 2016, 6, 34338. [CrossRef]

31. E Selick, H.; Kreuzer, K.N.; Alberts, B.M. The bacteriophage T4 insertion/substitution vector system. A method for introducing site-specific mutations into the virus chromosome. J. Biol. Chem. 1988, 263, 11336-11347. [CrossRef]

32. Kutter, E.; Sulakvelidze, A. Bacteriophages: Biology and Applications, 1st ed.; CRC Press: Boca Raton, FL, USA, 2004.

33. Kropinski, A.M.; Mazzocco, A.; Waddell, T.; Lingohr, E.; Johnson, R.P. Enumeration of Bacteriophages by Double Agar Overlay Plaque Assay. In Bacteriophages: Methods and Protocols; Clokie, M.R.J., Kropinski, A.M., Eds.; Humana Press: New York, NY, USA, 2009; pp. 69-76.

34. Hiramatsu, R.; Matsumoto, M.; Sakae, K.; Miyazaki, Y. Ability of Shiga Toxin-Producing Escherichia coli and Salmonella spp. to Survive in a Desiccation Model System and in Dry Foods. Appl. Environ. Microbiol. 2005, 71, 6657-6663. [CrossRef]

35. Lee, C.; Choi, I.Y.; Park, D.H.; Park, M.-K. Isolation and characterization of a novel Escherichia coli O157:H7-specific phage as a biocontrol agent. J. Environ. Health Sci. Eng. 2020, 18, 189-199. [CrossRef]

36. Ramirez, K.; Cazarez-Montoya, C.; Lopez-Moreno, H.S.; Campo, N.C.-D. Bacteriophage cocktail for biocontrol of Escherichia coli O157:H7: Stability and potential allergenicity study. PLoS ONE 2018, 13, e0195023. [CrossRef] [PubMed]

37. Lee, H.; Ku, H.-J.; Lee, D.-H.; Kim, Y.-T.; Shin, H.; Ryu, S.; Lee, J.-H. Characterization and Genomic Study of the Novel Bacteriophage HY01 Infecting Both Escherichia coli O157:H7 and Shigella flexneri: Potential as a Biocontrol Agent in Food. PLoS ONE 2016, 11, e0168985. [CrossRef] 
38. Filho, R.L.A.; Higgins, J.P.; Higgins, S.E.; Gaona, G.; Wolfenden, A.D.; Tellez, G.; Hargis, B.M. Ability of Bacteriophages Isolated from Different Sources to Reduce Salmonella enterica Serovar Enteritidis In Vitro and In Vivo. Poult. Sci. 2007, 86, 1904-1909. [CrossRef] [PubMed]

39. Bach, S.J.; McAllister, T.A.; Veira, D.M.; Gannon, V.P.; Holley, R.A. Effect of bacteriophage DC22 on Escherichia coli O157:H7 in an artificial rumen system (Rusitec) and inoculated sheep. Anim. Res. 2003, 52, 89-101. [CrossRef]

40. Hyman, P. Phages for Phage Therapy: Isolation, Characterization, and Host Range Breadth. Pharmaceuticals 2019, 12, 35. [CrossRef] [PubMed]

41. Snyder, A.B.; Perry, J.J.; Yousef, A.E. Developing and optimizing bacteriophage treatment to control enterohemorrhagic Escherichia coli on fresh produce. Int. J. Food Microbiol. 2016, 236, 90-97. [CrossRef] [PubMed]

42. Sharma, M.; Patel, J.R.; Conway, W.S.; Ferguson, S.; Sulakvelidze, A. Effectiveness of Bacteriophages in Reducing Escherichia coli O157:H7 on Fresh-Cut Cantaloupes and Lettucet. J. Food Prot. 2009, 72, 1481-1485. [CrossRef]

43. Minh, D.H.; Minh, S.H.; Honjoh, K.-I.; Miyamoto, T. Isolation and bio-control of Extended Spectrum Beta-Lactamase (ESBL)producing Escherichia coli contamination in raw chicken meat by using lytic bacteriophages. LWT 2016, 71, 339-346. [CrossRef]

44. Wang, C.; Chen, Q.; Zhang, C.; Yang, J.; Lu, Z.; Lu, F.; Bie, X. Characterization of a broad host-spectrum virulent Salmonella bacteriophage fmb-p1 and its application on duck meat. Virus Res. 2017, 236, 14-23. [CrossRef]

45. Guenther, S.; Herzig, O.; Fieseler, L.; Klumpp, J.; Loessner, M.J. Biocontrol of Salmonella Typhimurium in RTE foods with the virulent bacteriophage FO1-E2. Int. J. Food Microbiol. 2012, 154, 66-72. [CrossRef]

46. Bigot, B.; Lee, W.-J.; McIntyre, L.; Wilson, T.; Hudson, J.; Billington, C.; Heinemann, J. Control of Listeria monocytogenes growth in a ready-to-eat poultry product using a bacteriophage. Food Microbiol. 2011, 28, 1448-1452. [CrossRef]

47. Hagens, S.; Offerhaus, M.L. Bacteriophages-New weapons for food safety. Food Technol. 2008, 62, 46-54. Available online: https:/ / www.ift.org/news-and-publications/food-technology-magazine/issues/2008/april/features/bacteriophagesnew-weapons-for-food-safety (accessed on 30 May 2021).

48. Hudson, J.; Billington, C.; Cornelius, A.; Wilson, T.; On, S.; Premaratne, A.; King, N. Use of a bacteriophage to inactivate Escherichia coli O157:H7 on beef. Food Microbiol. 2013, 36, 14-21. [CrossRef] [PubMed]

49. Abedon, S.T. Phage therapy dosing: The problem(s) with multiplicity of infection (MOI). Bacteriophage 2016, 6, e1220348. [CrossRef] [PubMed]

50. Sulakvelidze, A. Using lytic bacteriophages to eliminate or significantly reduce contamination of food by foodborne bacterial pathogens. J. Sci. Food Agric. 2013, 93, 3137-3146. [CrossRef] [PubMed] 